\title{
EEmerald $\begin{aligned} & \text { Chinese Management } \\ & \text { Studies }\end{aligned}$
}

\section{Innovation with Chinese Characteristics: Theory and Practice}

\begin{tabular}{|r|l|}
\hline Journal: & Chinese Management Studies \\
\hline Manuscript ID & CMS-01-2020-0001 \\
\hline Manuscript Type: & Editorial \\
\hline
\end{tabular}

\section{SCHOLARONE ${ }^{m}$ \\ Manuscripts}




\title{
Innovation with Chinese Characteristics: Theory and Practice
}

\begin{abstract}
Purpose - This special issue of Chinese Management Studies aims to engage with debates on innovation in China and to provide new insights for innovation research in the context of China, seeking to develop a greater understanding of the concept of "innovation with Chinese characteristics".

Design/methodology/approach - Review and reflection.

Findings - The nine articles that constitute this special issue present research on important aspects of innovation in China, ranging from the effectiveness of government subsidisation for innovation, the impact of fiscal decentralisation on innovation, the role of management behaviour in promoting (or discouraging) innovation and the effects of differing business models on innovation. These articles shed valuable new light on the theory and practice of innovation in China. The articles are discussed in the context of four primary arguments about innovation management in China identified from the broader literature in the field. These relate to the pattern of China's innovation performance over time, the reasons for its effectiveness, the role of alliances and influences of indigenous factors. It is also shown that management of the internationalisation of innovation and of efficient internal innovation are two important directions for future research on Chinese innovation in an era of de-globalisation.

Originality/value - The studies presented here provide valuable contributions to theory building in innovation research, as well as some important ideas for directions of future research on innovation in China in the new era of de-globalisation.
\end{abstract}

Keywords Innovation, China, de-globalisation, internationalisation of innovation, R\&D efficiency

Paper type Editorial paper 


\section{Introduction}

When China embarked on its reform and opening-up drive in 1979, the country made modernisation of science and technology one of the four pillars of the new initiative. Forty years on, China has transformed itself from an impoverished, economically backward country into the world's second largest economy and, equally impressively, from a backwater of global innovation to a country recognised as the world's hub of science and innovation (Li \& Wang, 2013). China's remarkable progress in innovation has been well-documented (e.g. Ding \& Li, 2015; Fu, 2015). Yet, the characterisation of the Chinese approach to innovation management remains an area where arguments continue to be put forward and theories contested.

Over the years, four key primary arguments as to China's innovation management have emerged. First, Chinese innovation management is framed in terms of an evolutionary economics paradigm. This argument contends that Chinese innovation has followed a conventional catch-up pattern for latecomers to an economic field, in which that agent starts with learning from frontrunning countries before moving up the innovation ladder, as suggested by evolutionary economics theory (Nelson, 2008). Through this lens, it is argued that China's successful catch-up can be attributed to its institutions of knowledge creation and learning as well as its access to foreign knowledge ( $\mathrm{Li}, \mathrm{Li} \& \mathrm{He}, 2018$ ). For example, Lee, Jee and Eun (2011) identify several elements of learning and access strategies of the Chinese catch-up model that are unique to China and not found in the corresponding models of Taiwan or Korea. These unique features include: (1) parallel (indirect) learning from foreign direct investment (FDI) firms, (2) "forward engineering" (a role performed by university spin-off firms) in contrast to reverse engineering adopted in Korea and Taiwan, and (3) acquisition of technology and brands through international mergers and acquisitions (M\&As) and going global (zouchuqu) at an earlier stage of economic development. Along this line, Bound, Saunders, Wilsdon and Adams (2013) have referred to China as an "absorptive state" that has become increasingly adept at attracting and profiting from global knowledge and networks.

A second argument attributes Chinese innovation management to the country's ability to compete successfully on the elements of creativity and cost (Economist, 2010). This ability to make established products at dramatically lower cost is dubbed "frugal innovation" in broad terms (Zeschky, Widenmayer \& Gassmann, 2011). In this model, innovation is primarily concerned with redesigning products, using existing technology in imaginative new ways, and applying mass production techniques across the value chain. Frugal innovation not only addresses the unmet or underserved market needs of customers at the bottom of the pyramid but it also provides an impetus for innovation in other forms that is made possible by the expansion of markets.

While the phenomenon of shanzhai innovation that emerged in China in the 1980s has been seen as part of the "frugal innovation" model (Economist, 2010), more recent studies consider shanzhai to be a much broader phenomenon than just the cheap copying of goods. For example, Zhu and Shi's (2010) research points out that shanzhai manufacturing is typified by the rapid production cycle of the products - concept to delivery is often achieved within weeks. Keane and Zhao (2012) view shanzhai innovation as an example of rapid prototyping. Liu, Xie and $\mathrm{Wu}$ (2015) emphasise the importance of modularisation and the evolution of value chains in shanzhai innovation that significantly lower the technological threshold of entering markets such as the mobile phone business, promote disruptive innovations, and accelerate latecomers' accumulation of knowledge and technology. In more specific terms, the evolution of value chains leads to an outcome in which some firms in possession of better technologies can refocus their business on the design and production of chipsets and software, while others with other 
advantages such as market information can reallocate their efforts towards cosmetic design, differentiation, or marketing. For Maarten Beekers, ${ }^{1}$ a US technology commentator, the practice of shanzhai represents an open-source approach to manufacturing, which enables factories to bootstrap new products and penetrate new markets, all in a highly efficient way. This is made possible as manufacturing industries in China have developed, and traditional contract manufacturers have also grown in size, mainly catering to multinational brands. Some young entrepreneurs have seen this as an opportunity to start producing goods, in smaller volumes, for small and medium enterprises (SMEs). As a result, during the 1990s in particular a dense network of small manufacturing businesses emerged in China comprising component producers, traders, design houses, vendors and assembly lines.

A third interesting argument frames Chinese innovation management in accordance with the model of 'alliance capitalism' (Higgins, 2015). This is defined as a strategic approach in which government actors and firms develop embedded relational ties and collaborative R\&D activity with other firms and economic and technological actors in order to engage in innovative upscaling and product development. The primary goal of such alliances is to anticipate future market and ecosystem requirements and to use this information to build a critical network of interdependent alliance partners that are focused on achieving technological "convergence" and "interoperability" across the ecosystem platform.

In conclusion, a fourth research approach explores the emergence of China's indigenous innovation capabilities as being driven by China's ambitions in this field (Vinig \& Bossink, 2015). Such research emphasises the development of Chinese innovation based on a view of the country leading and developing innovation theory independently in its own right rather than merely using and building on Western-centric innovation theory. Chinese innovation efforts are strongly science-based and technology driven, aimed at moving China towards selfsufficiency as an innovation-based economy. Relevant questions that arise in this context are: should new theoretical approaches to theorising China-based innovation be considered? Should the specific context of each activity China conducts itself be the basis of theorising? Is the innovation system of China intrinsically and completely different from that of Western countries, or do they share some fundamentals and differ on others?

Despite the growing literature on Chinese innovation, consensus as to a unique model of Chinese innovation management has yet to emerge. However, the papers collected in this special issue seek to provide a number of new and important research frameworks relating to various aspects of innovation in China and so shed further light on this topic and advance our understanding of the concept of "innovation with Chinese characteristics".

\section{Overview of the special issue}

In terms of China's economy, the year 2018 was celebrated as the $40^{\text {th }}$ anniversary of China's embarkation on the process of reform and opening-up. To mark this significant milestone, Jilin University and Amsterdam Business School joined together to convene the $5^{\text {th }}$ Global Entrepreneurship and Innovation Conference in Amsterdam on the theme of "Technology Entrepreneurship - The Driving Force of Contemporary Business" on 11-12 October 2018. To facilitate the dissemination of the outstanding research produced for this conference, Chinese Management Studies (CMS) agreed to publish a special issue on the topic of "Innovation with Chinese Characteristics: Theory and Practice". The nine papers presented in this special issue have been selected from 49 submissions and have been subject to the journal's blind peerreview process. The articles in this CMS special section on Innovation with Chinese 
Characteristics highlight a number of specific features of innovation in China and issues that it involves. As such, the articles address issues ranging from the effectiveness of subsidisation of innovation, the impact of fiscal decentralisation and the role of management behaviour to the effects of different business models on this process.

In the first article, $\mathrm{Li}$, Zhou, Jung and Li provide an up-to-date review of the evolution of policies and practices of innovation in China over the last 40 years and identify six practices in particular that have underpinned the success of innovation in China over this period. Echoing Ding and Li (2015), they argue that good practices in managing innovation have consisted of formulating successive policies to encourage innovation and carrying out planning strategically, thus allowing space for spontaneity of creativity and encouraging "grassroots innovation", while using both the "invisible hand" and the "visible hand" to support innovation. They also argue that success for Chinese innovation has also resulted from the country's effort to engage state-owned and privately owned firms in collaborative innovation, so as to encourage internationalisation of innovation under the principles of "going out" and "bringing in", as manifested in the latest steps in the Belt and Road Initiative (BRI), and to release the entrepreneurial spirit of the Chinese people and to embrace the culture of "common destiny" as a new win-win model in international relations and future innovation-driven development.

The next three articles focus on government policies relating to subsidisation of research and development (R\&D) and fiscal decentralisation. Wang, Hu and Yang examine the effect of government subsidies on China's regional innovation performance, using the Bayesian model averaging (BMA) method. Subsidies are shown to be an important policy tool as the authors outline that China's R\&D subsidies for high-tech industries increased from CNY 3.910 billion in 2006 to CNY 210.183 billion in 2015, an average annual growth rate of $43.8 \%$. The authors use the proportion of government funds in the internal expenditure of $R \& D$ funds to measure the degree of government R\&D subsidies for high-tech industries, and new product sales revenue of high-tech industries to measure regional innovation performance. Their empirical results show that government subsidies have a negative relationship with regional innovation output. They interpret this result as evidence of the crowding-out effect, meaning that firms use government subsidies to substitute for their own R\&D investment.

Taking a different approach, Wang, Li and Sun examine the effect of government R\&D subsidies on firm performance, using Chinese A-share listed company data from 2008 to 2016. They find a positive impact of R\&D subsidies on return on assets (ROA) after controlling for a range of corporate characteristics, suggesting a positive effect for government $R \& D$ subsidies on firm performance. They also find that the relationship between R\&D subsidies and ROA is non-linear, indicating that it is only when $R \& D$ subsidies are given within a moderate interval that firms can perform better. The authors argue that $R \& D$ subsidies play a vital role in enhancing firm performance mainly via two mechanisms, namely signal financing and innovation incentives. Finally, they find evidence that suggests that the effect of government R\&D subsidies is greater in non-state-owned, more recently established, and large enterprises.

Focusing on a novel issue in the field, Yang, $\mathrm{Li}$ and Li examine the impact of fiscal decentralisation on city innovation performance in China, using a panel data of China's 278 cities from 2003 to 2016. The authors use the ratio of city budgetary expenditure per capita to the sum of central, provincial and city budgetary expenditure per capita to measure the degree of fiscal decentralisation. They estimate a patent renewal model and aggregate the forecast market value of the patent at the city level to construct an index of city innovation. Their research finds that fiscal decentralisation has significantly inhibited city innovation and that 
this inhibiting effect demonstrates the characteristics of a "V" type variation. They argue that the reasons behind this negative effect are twofold: fiscal decentralisation weakens the central government's ability to guide local governments to implement its innovation-driven strategy; and fiscal decentralisation weakens the central government's ability to restrain local governments' preference for self-interest in favoring investments emphasising production and neglecting innovation. They further show that the influence of fiscal decentralisation on city innovation presents clear spatial and temporal heterogeneity. Geographically, the inhibition of fiscal decentralisation on city innovation in eastern China is significantly weaker than that in central and western China. Temporally, after the implementation of China's innovation-driven development strategy in 2013, the negative impact of fiscal decentralisation on city innovation disappeared.

The focus of the next three articles shifts to firm behaviour and its impacts. Hai, Yin, Gao and Chen analyse the impact of R\&D volatilities on market value and the moderating effect of executive overconfidence, employing a panel dataset covering 902 Shanghai and Shenzhen Ashare manufacturing listed firms. In this context, R\&D volatilities indicate shifts in a firm's innovation strategies between exploratory innovation (positive shift) and exploitative innovation (negative shift), as reflected by changes in R\&D expenditure away from the firm's historic trend. The authors find that positive $R \& D$ volatilities have a significant positive impact on market value, suggesting that the shift of innovation strategy to exploratory innovation helps firms change the trajectory of technological development and acquire competitive advantage which in turn enhances their market value. They also find that negative R\&D volatilities have a significant positive impact on market value, indicating that the shift from exploratory innovation to exploitative innovation helps firms to consolidate competitive advantage and achieve better performance. Finally, they report that the relationship between R\&D volatilities and market value is moderated by executive overconfidence.

Dai and Taube explore the functionality of long tail markets (LTM) in new products and business development through two Chinese cases: the Fintech sector and low-speed electric vehicles (LSEV). They argue that the alternative approach of leveraging LTM for new business models and technologies rather than competing head-on with powerful incumbents in the mainstream markets promotes the introduction of new technologies and business models. Their research identifies three strategies to explore LTM for businesses, i.e. identifying a specific customer base, being aware of localisation products, and dealing skilfully with regulations.

Focusing on a concept relevant to many aspects of China's society and economy, Zhao and Vinig investigate how guanxi and guanxi intensity may affect reward-based crowdfunding success and project performance in the Chinese context, using research data on 989 crowdfunding projects collected from China's largest reward-based crowdfunding platform zhongchou.com over the one-year period January-December 2014. They find that project developers' guanxi-building behaviour displayed before launching their own projects, through for example being supportive of other projects, is positively related to project success. In addition, the intensity of guanxi-building behaviour positively influences project performance in a significant way. Moreover, the establishment and maintenance of project developers' guanxi with funders during the fundraising process are also positively associated with project success and fundraising performance.

The final two articles in this special issue turn to broader studies. Sun and Ai investigate the effect of home political connections on the cost structures of Chinese multinationals. Framing their research in terms of social exchange theory, the authors argue that the costs of home 
political connections arising from reciprocity commitments to the government in outbound M\&As of Chinese multinationals outweigh the benefits. The costs are higher for lower-level political connections. Using a sample of $225 \mathrm{M} \& \mathrm{~A}$ deals, they test and confirm the negative effect of home political connections on the internationalisation of Chinese multinationals. Also, the negative impact of lower-level political connections is stronger than that of their higherlevel counterparts.

Zhu and Fang provide a systematic review of the literature over the period 2000 to 2018, in Chinese and English, presenting research on innovation performance. Based on the systematic literature review, the authors identify three characteristics of the research in this specific domain. First, the momentum of research on innovation performance in the English literature has been increasing, whereas that in the Chinese literature has declined in recent years. Second, research in both Chinese and English literature has covered similar streams such as "innovation system/elements", "innovation activity/ability" and "innovation network/social capital". Third, although the directions are the same, the specific contents of research have been different. The "hot topics" in the English literature have been "sourcing knowledge" and "culture value" in the "innovation system/elements" stream, "supply chain management" (SCM) in the "innovation activity/ability" stream, and "licensed-knowledge attributes" in the "innovation network/social capital" stream. By contrast, the "hot topics" in the Chinese literature have been "technology transfer" in the "innovation system/elements" stream, "resource acquisition" and "external innovation search" in the "innovation activity/ability" stream, and "cooperation experiences" in the "innovation network/social capital" stream. Using insights obtained from this review, the authors propose three directions for future innovation performance research: expanding research in hot topics, connecting research streams to extend research scope, and exploring new fields of innovation performance.

\section{Some future research directions in the era of de-globalisation}

Following the overview of the research in this special issue presented above, it is appropriate to make a few brief observations here about the current international environment in which innovation must take place at present, and some of the key research questions that this gives rise to as to the most effective future path for China's innovation efforts.

The world has changed significantly since the global financial crisis of 2008. Slow global economic growth has become the new normal, global trade protectionism is rising, cross-border flows of trade, finance and investment are declining, global supply chains are disintegrating, and the current rules of the world trading system are being challenged. This unfolding retreat of globalisation is termed de-globalisation. The international trade policies that have headlined the first three years of the Trump presidency in the US have brought about a spurt in the pace of de-globalisation. These developments will necessarily affect both the nature and rate of China's innovation process. Specifically, the technology contest that is part of the US-China trade war will have a far-reaching effect on Chinese innovation. As the Economist has noted, the trade conflict that matters most between America and China is a $21^{\text {st }}$-century fight over technology. ${ }^{2}$ With the determination of the US to deter China's rise to becoming a technology leader and China's resolve to move up the technology ladder, both countries could find it difficult to reconcile their respective national interests. There is a real danger that the technology contest could lead to the decoupling of science and technological innovation between the world's two largest economies, dividing the world's R\&D chain into two parallel innovation ecosystems. ${ }^{3}$ The new era of globalisation and the economic and social problems 
behind it require critical review of, and reflection on, the theory, practice and policies of innovation in China, and fresh thinking about new models of innovation.

Despite the rise of nationalism and retreat of globalisation, the underlying factors favouring open innovation in fact still hold. On the one hand, good ideas and innovation will undoubtedly continue to flow as a result of the processes of connecting, fusing and recombining by economic agents and policy-makers and established patterns and understandings will reinvent themselves by crossing conceptual, organisational and national borders. On the other hand, no one can establish supremacy in all fields in the light of the complexities of today's technologies and supply chains. Hence, the ongoing technology contest between the US and China does not support the argument that China should turn its back to open innovation by reverting to an aim of self-sufficiency in technologies. The scale of China's home market may indeed provide Chinese firms with an indispensable cushion against the damaging forces released from the technology contest for the time being. However, by focusing innovation exclusively on the home market Chinese companies could fall into the trap of cutting themselves off from the wider world and the bigger ideas it contains.

Nonetheless, the changing environment also suggests that the balance between internal and external resources has shifted, because developing and possessing internal R\&D capabilities can be argued to be more important when there exists a heavy reliance on relationships with other actors. This calls for a greater understanding of different forms and practices of openness. In this context, management of internationalisation of innovation and management of efficient internal innovation are two important directions for research on Chinese innovation going forward.

\subsection{Management of internationalisation of innovation}

The internationalisation of innovation by Chinese firms over the last decade has typically taken one of three forms. The first was to use business joint ventures and setting-up of research centres abroad to access and generate cutting-edge technologies from the host countries. For example, Huawei has set up 36 joint innovation centres and 16 research centres worldwide. ${ }^{4}$ The second was to use mergers and acquisitions (M\&As) to obtain technologies critical for Chinese firms to advance in the value chain. The third was to use corporate venture funds to invest in technology start-ups in the US and Europe in order to have a stake in emerging technologies. Traditionally, a firm's collaboration with external partners has been seen to entail two types of costs (Grant, 1996), i.e. the costs of coordination and competition. Costs of coordination emerge from organisations that are different, where it may be difficult to bridge organisational boundaries. Costs of competition emerge from the risk that one actor might act opportunistically in bad faith. However, the US's recent ban on technology exports to Huawei indicates another form of cost emerging from the firm's deep dependence on external core technologies - costs of strategic control. Clearly, openness is beneficial only when the firm chooses the correct and concomitant configuration of both the open and the closed resource (Alexy, West, Klapper \& Reitzig, 2018). In 2010, Dahlander \& Gann asked: How open is innovation? The question remains relevant today.

In the face of the US ban, Huawei's response so far has been revealing. First, in spite of facing being cut off from the American technology supply and being barred from joining the global research chain (as shown, for example, by the fact that in the wake of the sanctions, Stanford University and MIT in the US, and the University of Oxford in the UK, cut funding ties with Huawei), the company maintained that it would still embrace American technologies so long as they are made available to them. It was also determined to keep their innovation system 
open. In doing that, the company has reallocated its R\&D investment globally to mitigate the effect of US ban. For example, it was reported that in October 2019 Huawei had bought a stake in Oxford Sciences Innovation that commercialises research at Oxford University, which would give the company access to some of the most promising early stage technology developed by academics in the UK. ${ }^{5}$ Second, the company quickly revealed that it had secretly worked on its own proprietary operating system named as HarmonyOS for nearly ten years and would install it in their smartphone products should the company's access to Google's android system be blocked completely. Third, the company announced that it would invest USD 1.5 billion to support application developers world-wide to nurture the development of its own innovation ecosystem. ${ }^{6}$

The case of Huawei suggests a number of questions that future research on Chinese innovation needs to tackle. What are the firm- or environmental-level factors that may moderate the effect of openness on competitive advantage? How should firms in China balance generic, non-firm specific R\&D with strategic, firm specific R\&D? What strategy could represent a win-win approach to internationalising $R \& D$ ? In terms of the internationalisation of $R \& D$, how should firms in China manage intra- and inter-regional geographic diversification? How should Chinese firms develop innovation ecosystems? How could firms in China utilise government support to deal with the challenges of de-globalisation? How could firms in China deal with institutional pressures from host countries?

\subsection{Management of efficient internal innovation}

The new era of de-globalisation compels firms in China to find a balance between a search for external sources of innovation and the development of internal innovation capabilities. While adapting the process of internationalisation of $R \& D$ to the new era of de-globalisation is imperative, equally important for Chinese firms is to improve innovation efficiency. China's innovation drive over the past several decades has been supported by the unprecedented level of funding directed to R\&D. For example, China spent over CNY 1.96 trillion (around USD 293 billion) on R\&D in 2018, up 11.6 per cent compared with the level in 2017. ${ }^{7}$ In 2019, China established a new state-backed semiconductor fund worth USD 28.9 billion in order to advance its domestic semiconductor R\&D and reduce its reliance on US technology. ${ }^{8}$ China's incentive for injecting more resources into its innovation system to support $R \& D$ in general and strategic industries in particular will be certainly strong if the technology contest lingers on. Yet, the concern is that the productivity of $R \& D$ investment in China overall has been unsatisfactory. There is consistent evidence pointing to the low R\&D efficiency of firms in China. As but one example, empirical research using data on 38 Chinese new energy enterprises from 2009 to 2013 found that new energy enterprises are generally inefficient when it comes to innovating (Wang, Hang, Sun \& Zhao, 2016). It has also been found that state ownership enables firms to obtain crucial R\&D resources but makes them less efficient in using those resources to generate innovation (Li \& Li, 2014; Zhou, Gao \& Zhao, 2017). As a result, the level of inputs is not consistently translated into successful innovation outputs. Kennedy (2017) characterises this economy characterised by low transformation of inputs into successful high-tech advancement as a "fat" tech dragon. It is not a surprise that a recent meta-analysis of the relevant literature on a large number of countries at different stages of economic development found that the growth-enhancing effect of R\&D spending in China has been significantly weaker than that in other countries (Ljungwall \& Tingvall, 2015).

The underlying causes of innovation inefficiency in China are multifaceted. At the innovation support system level, the problems relate to the duplication of science and technology (S\&T) projects, lack of transparency in S\&T management, and low efficiency in fund use (Ding \& Li, 
2015). At the regional level, the problems are found to be related to a mismatch between upstream public research organisation-centred research processes and downstream firmcentred commercialisation processes when the downstream commercialisation process plays a more important role in the innovation processes in the region as a whole (Chen \& Guan, 2012). At the firm level, the problems are found to be linked with the low absorptive capacity for the potential outputs of the increasing R\&D inputs and the inefficiency of the technology commercialisation processes (Han, Thomas, Yang, Ieromonachou \& Zhang, 2017). Important research questions will be: how could government agencies work collaboratively to identify and support novel S\&T projects? How could governments make the funding mechanism of S\&T projects fair and transparent? How could S\&T fund be used more efficiently? How could regional innovation systems align upstream public research organisation-centred research processes and downstream firm-centred commercialisation processes more closely? How could firms improve their absorptive capacity? How could firms enhance the efficiency of technology commercialisation processes?

\section{References}

Alexy, O., West, J., Klapper, H., \& Reitzig, M. (2018). Surrendering control to gain advantage: Reconciling openness and the resource-based view of the firm. Strategic Management Journal, 39(6), 1704-1727.

Bound, K., Saunders, T., Wilsdon, J., \& Adams, J. (2013). China's absorptive state: Research, innovation and the prospects for China-UK collaboration. London, Nesta.

Chen, K., \& Guan, J. (2012). Measuring the efficiency of China's regional innovation systems: Application of network data envelopment analysis (DEA). Regional Studies, 46(3), 355377.

Dahlander, L., \& Gann, D. M. (2010). How open is innovation?. Research policy, 39(6), 699709.

Ding, X., \& Li, J. (2015). Incentives for innovation in China: Building an innovative economy. London, Routledge.

$\mathrm{Fu}, \mathrm{X}$. (2015). China's path to innovation. Cambridge University Press.

Grant, R. M. (1996). Toward a knowledge-based theory of the firm. Strategic Management Journal, 17(S2), 109-122.

Han, C., Thomas, S. R., Yang, M., Ieromonachou, P., \& Zhang, H. (2017). Evaluating R\&D investment efficiency in China's high-tech industry. The Journal of High Technology Management Research, 28(1), 93-109.

Higgins, V. (2015). Alliance capitalism, innovation and the Chinese state: The global wireless sector. Basingstoke, Palgrave-Macmillan.

Keane, M., \& Zhao, E. J. (2012). Renegades on the frontier of innovation: The shanzhai grassroots communities of Shenzhen in China's creative economy. Eurasian Geography and Economics, 53(2), 216-230.

Kennedy, S. (2017). The fat tech dragon: Benchmarking China's innovation drive. Washington, DC, Center for Strategic \& International Studies.

Lee, K., Jee, M., \& Eun, J.-H. (2011). Assessing China's economic catch-up at the firm level and beyond: Washington Consensus, East Asian Consensus and the Beijing Model. Industry and Innovation, 18(5), 487-507.

Li, J., \& Wang, L. (Eds.). (2013). China's economic dynamics: A Beijing Consensus in the making?. London, Routledge.

Li, Z., \& Li, J. (2013). State-owned enterprises in China's transition to an innovation-driven economy. In Li, J., \& Wang, L. (Eds.). China's economic dynamics: A Beijing Consensus in the making?, London, Routledge. 193-203. 
Li, Z., Li, J., \& He, B. (2018). Does foreign direct investment enhance or inhibit regional innovation efficiency? Evidence from China. Chinese Management Studies, 12(1), 35-55.

Liu, X., Xie, Y., \& Wu, M. (2015). How latecomers innovate through technology modularization: Evidence from China's Shanzhai industry. Innovation, 17(2), 266-280.

Ljungwall, C., \& Tingvall, P. G. (2015). Is China different? A meta-analysis of the growthenhancing effect from R\&D spending in China. China Economic Review, 36, 272-278.

Nelson, R. R. (2008). What enables rapid economic progress: What are the needed institutions?. Research Policy, 37(1), 1-11.

Vinig T., Bossink B. (2015). China's indigenous innovation approach: The emergence of Chinese innovation theory? Technology Analysis and Strategic Management, 27(6), 621627.

Wang, Q., Hang, Y., Sun, L., \& Zhao, Z. (2016). Two-stage innovation efficiency of new energy enterprises in China: A non-radial DEA approach. Technological Forecasting and Social Change, 112, 254-261.

Zeschky, M., Widenmayer, B., \& Gassmann, O. (2011). Frugal innovation in emerging markets. Research-Technology Management, 54(4), 38-45.

Zhou, K. Z., Gao, G. Y., \& Zhao, H. (2017). State ownership and firm innovation in China: An integrated view of institutional and efficiency logics. Administrative Science Quarterly, 62(2), 375-404.

Zhu, S., \& Shi, Y. (2010). Shanzhai manufacturing-an alternative innovation phenomenon in China: Its value chain and implications for Chinese science and technology policies. Journal of Science and Technology Policy in China, 1(1), 29-49.

\footnotetext{
${ }^{1} \mathrm{https}$ ://chinatradeblog.org/shanzhai-manufacturing/ (accessed 5/11/2019)

2 The Economist (2018) Chip wars. December $1^{\text {st }}-7^{\text {th }} 2018$. p. 15

${ }^{3}$ Forced U.S.-China Decoupling Poses Large Threats, https://www.forbes.com/sites/harrybroadman/2019/09/30/forced-u-s-china-decoupling-poseslarge-threats/\#70c276b4598e (accessed 5/11/2019)

${ }^{4}$ Power of platforms - Huawei R\&D centers introduction https:/www.youtube.com/watch?v=insX10pmhCI (accessed 15/10/2019)

${ }^{5}$ Huawei buys access to UK innovation with Oxford stake, https://www.ft.com/content/28892c04-e453-11e9-b112-9624ec9edc59 (accessed 5/11/2019) ${ }^{6}$ Huawei proffers $\$ 1.5 \mathrm{bn}$ in bid to lure software developers, https://www.ft.com/content/a954455e-d9df-11e9-8f9b-77216ebe1f17 (accessed 5/11/2019)

${ }^{7}$ China's spending on R\&D rises to 2.18 pct of GDP. http://www.xinhuanet.com/english/2019-03/03/c 137865068.htm (accessed 6/11/2019) ${ }^{8}$ China establishes $\$ 28 \mathrm{bn}$ fund to wean itself off of US semiconductors. https://www.techspot.com/news/82556-china-establishes-29b-fund-wean-itself-off-us.html (accessed 6/11/2019)
} 